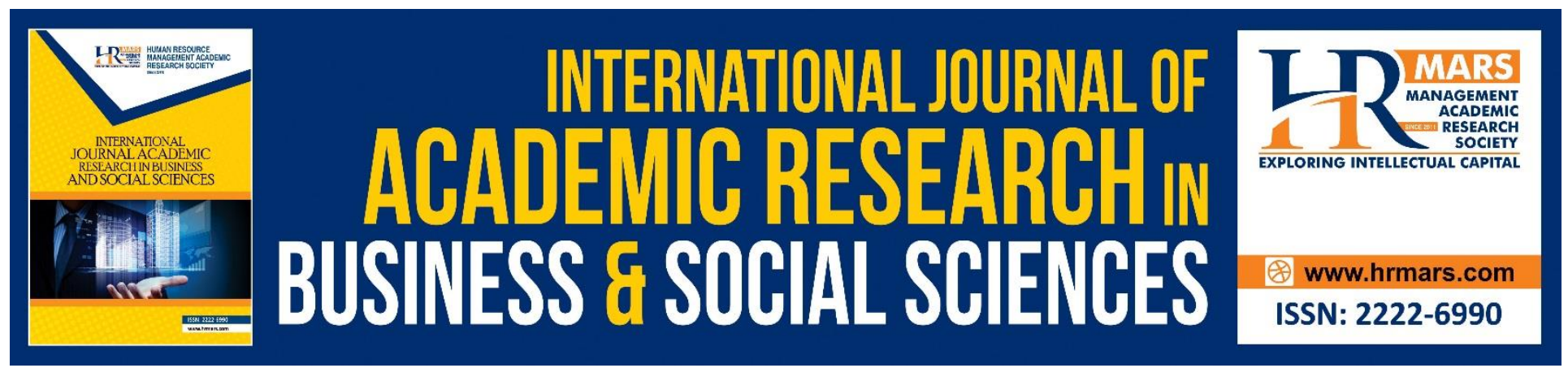

\title{
The Mediating Effect of Money Attitude on Association Between Financial Literacy, Financial Behaviour, and Financial Vulnerability
}

Mohamad Fazli Sabri, Husniyah Abd Rahim, Rusitha Wijekoon, Nurul Fardini Zakaria, Amirah Shazana Magli \& T. Syahrul Reza

To Link this Article: http://dx.doi.org/10.6007/IJARBSS/v10-i15/8254 DOI:10.6007/IJARBSS/v10-i15/8254

Received: 04 October 2020, Revised: 30 October 2020, Accepted: 21 November 2020

Published Online: 01 December 2020

In-Text Citation: (Sabri et al., 2020)

To Cite this Article: Sabri, M. F., Rahim, H. A., Wijekoon, R., Zakaria, N. F., Magli, A. S., \& Reza, T. S. (2020). The Mediating Effect of Money Attitude on Association Between Financial Literacy, Financial Behaviour, and Financial Vulnerability. International Journal of Academic Research in Business and Social Sciences, 10(15), 340-358.

\section{Copyright: (C) 2020 The Author(s)}

Published by Human Resource Management Academic Research Society (www.hrmars.com)

This article is published under the Creative Commons Attribution (CCBY 4.0) license. Anyone may reproduce, distribute, translate and create derivative works of this article (for both commercial and non-commercial purposes), subject to full attribution to the original publication and authors. The full terms of this license may be seen

at: http://creativecommons.org/licences/by/4.0/legalcode

Special Issue: Youth and Community Wellbeing: Issues, Challenges and Opportunities for Empowerment V1, 2020, Pg. 340 - 358 http://hrmars.com/index.php/pages/detail/IJARBSS

Full Terms \& Conditions of access and use can be found at http://hrmars.com/index.php/pages/detail/publication-ethics 


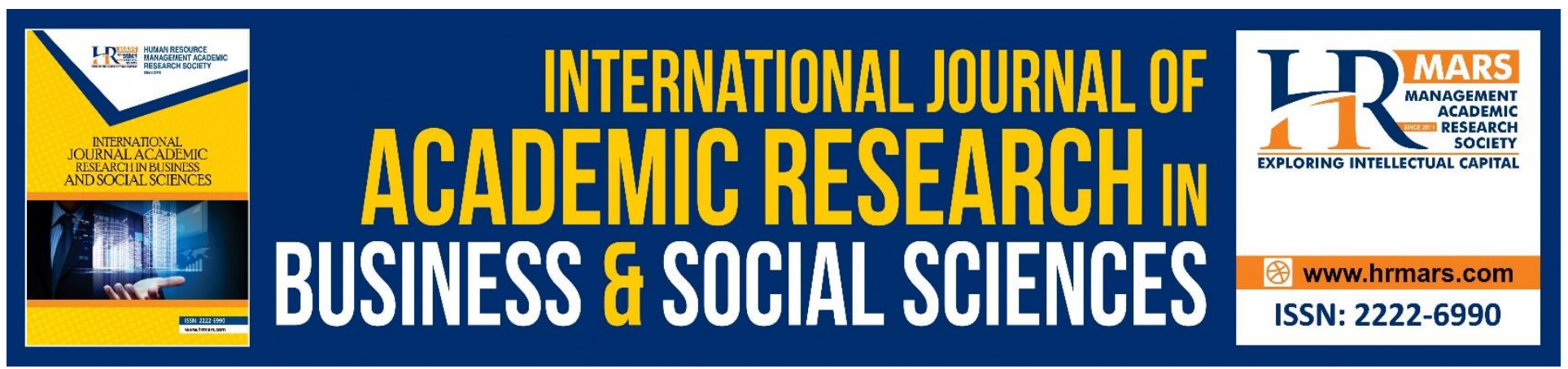

\title{
The Mediating Effect of Money Attitude on Association Between Financial Literacy, Financial Behaviour, and Financial Vulnerability
}

\author{
Mohamad Fazli Sabri ${ }^{1}$, Husniyah Abd Rahim², Rusitha Wijekoon ${ }^{3}$, \\ Nurul Fardini Zakaria ${ }^{4}$ Amirah Shazana Magli ${ }^{5}$ \& T.Syahrul Reza ${ }^{6}$ \\ ${ }^{1}$ Institute for Social Science Studies, Universiti Putra Malaysia, 43400 UPM Serdang, Selangor, \\ Malaysia. 2,3,4,5 Department of Resource Management \& Consumer Studies, Faculty of Human \\ Ecology, Universiti Putra Malaysia, 43400 UPM Serdang, Selangor, Malaysia. ${ }^{6}$ Institut IImu Sosial dan \\ Manajemen STIAMI, Jakarta, Indonesia \\ Email: fazli@upm.edu.my
}

\begin{abstract}
The financial vulnerability is associated negatively with all aspects of the life of each and every individuals and households of lower, middle and high income groups. Hence, the major objective of the study is to construct a financial vulnerability model for Malaysian households. The data collection was performed of a total of 574 respondents who were chosen following the multi-stage random sampling method. The Structural Equation Modelling (SEM) were utilized to perform the mediating test of money attitude on the association between personal finance and financial vulnerability, and the results revealed that the money attitude as a partial mediator. Moreover, the identified influential Malaysian households' personal financial factors will assist the related agencies to implement intervention programme that is leading to uplift the quality, and well-being of the life of the Malaysians as intended by the strategies outlined in the Eleventh Plan of the Malaysia.

Keywords: Personal Finance, Financial Literacy, Financial Behaviour, Money Attitude, Financial Vulnerability

\section{Introduction}

The impact of inflation was increasing the burden of Malaysian households as the price of consumer goods and services were increased. The impact of rising inflation and reducing subsidy were directly affecting the cost of living among households while the income was remaining the same. Therefore, households have to spend more than usual in order to maintain their previous situation. Empirical evidence was shown that the impact of high cost of living has badly affected on the household welfare (Granado et. al., 2012), and it has disproportionate impact on family well-being (Zainal et. al, 2012).
\end{abstract}


INTERNATIONAL JOURNAL OF ACADEMIC RESEARCH IN BUSINESS AND SOCIAL SCIENCES

Vol. 10, No. 15, Youth and Community Wellbeing: Issues, Challenges and Opportunities for Empowerment V1. 2020, E-ISSN: 2222-6990 @ 2020 HRMARS

Combination of a rising cost of living and poor financial behaviours lead households to become financially vulnerable.

Financial vulnerability is not just only connected with the households' financial well-being (FWB), but also has an effect on the individual efficiency at the workplace. Moreover, financial vulnerability also affects the household health, for example, loss of control, emotional distress, and anxiety (Choi, 2009), psychological distress (Gorgievski et. al., 2010), increase depressive symptoms (Aranda \& Lincoln, 2011), and similarly leads to family and relationship issues such as, domestic violence, separation, and divorce (Brown et. al., 2010).

The financial vulnerability of an individual or household can be caused due to numerous causes. Unplanned financial behaviours are regularly escorted by household financial issues, and the identified major reason for the household financial issues is poor financial illiteracy of the households (Lusardi \& Tufano, 2015). In addition to that, the integration of some financial issues, for example, low income, high debt, and lower degree of financial literacy might unfavorably influence the households' financial vulnerability. Review evidences were also proved that the psychological factors are also effect on household financial vulnerability (Chou \& Chi, 2001; Folkman et. al., 1986). Financial vulnerability implies how challenging families are just meeting their current financial obligations, with corresponding complications, and getting ready for the future. Therefore, facing to the financial vulnerability is essential to the households, because it offers opportunities to take life-changing decisions.

Hence, there is a need to understand, and identify those who are vulnerable, and the factors affecting financial vulnerability among Malaysian households. The current study determined the influence of personal finance (financial behaviour, financial literacy), and money attitude in contributing to the financial vulnerability of the Malaysian households. Hence, the major objective of the study was to reveal the relationships between financial behaviour, financial literacy, and money attitude with financial vulnerability among Malaysians who are working in the public sector. Specifically, the study has two objectives; 1 ) to find the relationship between financial behaviour, financial literacy, and financial vulnerability, and 2) to recognize the mediating role of the money attitude on the association between financial behaviour, financial literacy, and financial vulnerability.

\section{Literature Review}

Local studies have shown that most of the civil servants were associated with financial difficulties due to poor financial literacy, and financial management (Sabri \& Zakaria, 2015). Mishandling of the financial resources are ended up with the increasing cases of bankruptcy among public employees in Malaysia, and it is not only affected negatively on a single employee, but also affects their families, and the society. The gravity of this problem in some cases affecting their daily jobs such as, low productivity, lack of discipline, and bribery. There is a growing concern about the debt issues that are affected on Malaysian public employees. As stated by the Malaysian Department of Insolvency (MDI) report in 2011, number of public employees stated as bankrupts in 2009 was 1,086 due to the heavy debts. But, Mokhtar et. al. (2015) observed that the statistics have been raised up to 3,000 employees 
INTERNATIONAL JOURNAL OF ACADEMIC RESEARCH IN BUSINESS AND SOCIAL SCIENCES

Vol. 10, No. 15, Youth and Community Wellbeing: Issues, Challenges and Opportunities for Empowerment V1. 2020, E-ISSN: 2222-6990 @ 2020 HRMARS

in 2011. Therefore, studying of those financial difficulties which are associated with the Malaysian households is a current requirement.

An important role is performed by the Family Resource Management in assisting to overcome, and change the expanding complications faced by the households. It is the way of utilizing the assets to achieve its objectives via taking and planning the stages that are vital to achieve those goals. $A$ critical phase of the proper managing procedure is the assigning of the assets to achieve the target goals (Deacon \& Firebaugh, 1988). Therefore, the research framework of the study is based on the Family Resource Management Model (FRMM) which was introduced by Deacon and Firebaugh in1988. The current situation of the personal finance are the external inputs, which influence the internal inputs. The internal inputs of the current study are the respondent's financial behaviour, and financial literacy. The inputs go through the throughput, and the result is the observable output. The money attitude is the throughput in this study, and the observable output is the financial vulnerability (Figure 1).

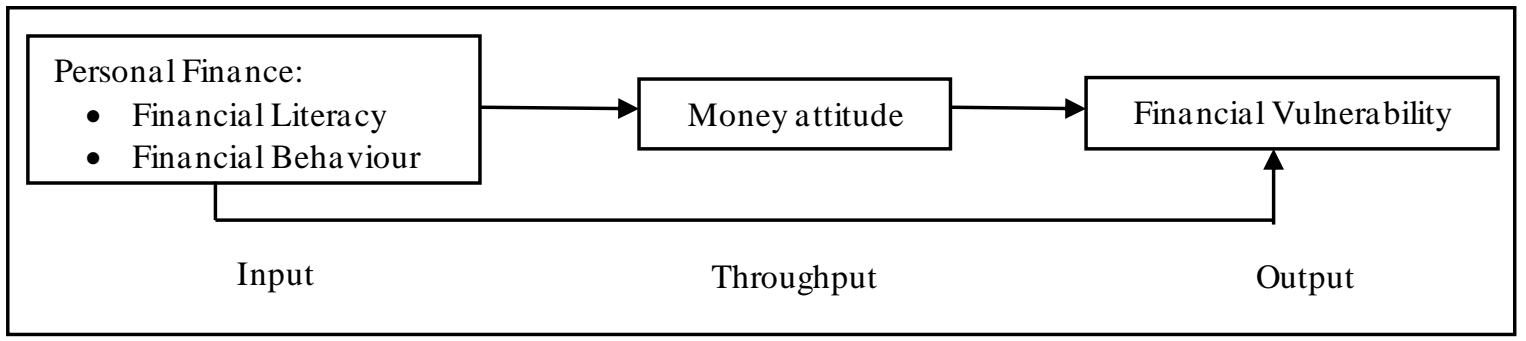

Figure 1 Conceptual framework

\section{Financial Vulnerability}

Vulnerability alludes to exposure to stresses and contingencies, and unable to cope with them (Chambers, 1989). "Financial vulnerability is indicated by an inability to maintain expenses, an inability to confront unexpected expenses, and an indebtedness or a declining real household net wealth to disposable income ratio" (De Clercq, et. al., 2015, p.115). When observing the existing trends, it is clear that the loans are taken by the individuals to overwhelmed the economic and financial complications as a response to the prevailing conditions (Anderloni et. al 2012). As a result of this loans, rather than controlling their utilization patterns, their savings are lost, and direct them to the financial vulnerability (Vandone, 2009). Yet, a concurred index for the financial vulnerability is not developed for the empirical analysis, and therefore, limited studies on the causes of the household financial vulnerability were done (Abid \& Shafiai, 2018).

Unsteady and insufficient income was the widely recognized trigger of the household financial vulnerability across different life transitions, and the resulted substitution is non-performing loans (Abdul Ghani, 2010). Moreover, individual characteristics such as, thrift and attitude towards credit influence, and unplanned financial decisions are also important to the financial vulnerability (Arashiro, 2011). Therefore, the suggested hypothesis is;

$H_{a} 1$ : A significant association is existed between money attitude and financial vulnerability. 


\section{Financial literacy}

An individual's ability and confidence to utilize the financial knowledge (Huston, 2010), and to take wise individual financial decisions (Lusardi \& Mitchell, 2014) are defined as the financial literacy. "Financial literacy is crucial for an individual with a combination of awareness, knowledge, skill, attitude, and behaviour, and it is also help an individual to make sound financial decisions, and ultimately individual financial well-being can be achieved" (OECD, 2013, p. 7). Low financial literacy caused financial problems (Idris et. al., 2013), and thus affect the individual decisions in managing income and influence a level of financial security (Lusardi \& Mitchell, 2007) especially in preparedness for retirements, level of saving, and ability to meet an emergency.

Being financially educated might be advantageous for an individual due to the gaining of a bunch of capacities and perspectives, for example, understanding of the concepts of money management, familiarization of financial bodies, and attitudes, which empower the managing capability of the financial affairs (Albeerdy \& Gharleghi, 2015). Money cause a significant issue on individuals, as a functional product, and as well as an emotional symbolization of worth or sense of representation (Engelberg \& Sjoberg, 2006). Moreover, financially literate individuals' FWB is higher, and further, a significant positive relationship was found between money attitude and FWB (Sabri et. al., 2020). Therefore, the suggested hypothesis is;

\section{$\mathrm{H}_{\mathrm{a}}$ 2: A significant association is existed between financial literacy and money attitude}

In addition, an individual that has a basic financial knowledge are able to keeping track of spending, budgeting and saving, and are bound to plan their retirement life properly (Lusardi \& Mitchell, 2011). Moreover, financial literacy has a noteworthy association with day-to-day individual financial practices (Boon et al., 2011). Lack of financial literacy influence on how individual manage income and determine the way of the individual perform financial practices in life. However, with better financial literacy helps individuals in making a sound financial decisions, and have a better plan on the retirement needs (Boon et al., 2011). Therefore, the financial vulnerability has an association with various factors, and influence by numerous variables such as, financial literacy. Moreover, the socioeconomic variables such as, education, age, race, gender, earning, and savings were also suggested to be an effect on financial vulnerability (Murphy, 2013). Hence, the developed hypothesis is;

$\mathrm{H}_{\mathrm{a}} 3$ : A significant association is existed between financial literacy and financial vulnerability.

\section{Financial Behaviour}

A good financial behaviour reflects some of the good financial activities, for example, making a budget, paying bills on time, making a plan for spending, cash flow management, managing credit, and plan for the retirement (Kapoor et. al., 2004). Further, good financial management practices like savings and investment behaviours are important for the Malaysian working women to manage their surplus money wisely in order to achieve higher FWB levels (Sabri et. al., 2020). Moreover, financial behaviour was found to have a noteworthy association with the level of financial knowledge (Ahmad et. al., 2016; Hilgert et. al, 2003; Zakaria et. al., 2012). Literature also found that financial behaviour 
INTERNATIONAL JOURNAL OF ACADEMIC RESEARCH IN BUSINESS AND SOCIAL SCIENCES

Vol. 10, No. 15, Youth and Community Wellbeing: Issues, Challenges and Opportunities for Empowerment V1. 2020, E-ISSN: 2222-6990 @ 2020 HRMARS

has a positive association with FWB (Zaimah et. al, 2013), financial satisfaction (Dowling et. al., 2009), and financial vulnerability (Miron-shatz, 2009). In contrast, the study by Fei et. al. (2020) revealed that financial behaviour is one of the noteworthy factors of the financial vulnerability of the young employees in Malaysia, and have a negative relationship with their financial vulnerability. In a study by Hayes and Finney (2013) have measured on how financial behaviour effect on the household financial vulnerability in measuring individual general financial position such as, an experience of financial difficulties, and projection of future financial position. Therefore, the proposed hypothesis is;

$H_{a} 4$ : A significant association is existed between financial behaviour and financial vulnerability.

Moreover, money is identified as an important motivator of financial behaviour, as well as a feature that shapes the job stress, and satisfaction (Albeerdy \& Gharleghi, 2015). Numerous financial studies have been concentrated to understand the financial influencers for example, financial literacy and money attitude due to the significance of understanding individuals' financial behaviour, and planning successful financial education systems to educate the employees of their institutions to limit unethical or illegal marketing exercises (Shih \& Ke, 2014). Accordingly, the suggested hypothesis is;

$H_{a} 5$ : A significant association is existed between financial behaviour and money attitude

\section{Money Attitude}

"Attitudes mean a tendency to behave toward the object so as to keep or get rid of it; in addition, attitudes are also a set of beliefs that the object is either good or bad" (Culbertson, 1968). The money attitudes might alter the manner of how something appear based on an individual's personal, cultural, and moral values towards the financial choices and items. An association between orientation toward money, and life satisfaction was revealed by Nickerson et. al. (2007). Further, they showed that the individuals who are obsessed with money or with high materialism have a possibility to be highly pleased with their financial state due to their capability to manage the material requirement cost. Yet, fundamentally fewer consideration is given to the symbolic and psychological features of money, when foreseeing the financial vulnerability. The comprehension of attitude towards the money, and the connection of those money attitudes towards the financial vulnerability might assist to perceive how the money variables incorporate with individuals' personality, social relationships, and economic activities, and their link with the FWB. The Theory of Planned Behaviour (TPB) suggests that the behavioural intention is influenced by attitudes, and the normative beliefs towards that behaviour (Montano \& Kasprzyk, 2015), and attitudes have been distinguished as a significant intervening element in financial literacy. Accordingly, the suggested hypothesis is;

$\mathrm{H}_{a} 6$ : Money attitude mediates the association between financial literacy and financial vulnerability

Both the financial behaviour, and money attitude are a typical explanation of worry among academicians, strategy makers, financial experts, anthropologists, psychologists, and sociologists for over last several decades (Qamar et. al., 2016). Several studies have identified the demographic variables, various characteristics of money that are linked with money attitudes, and the frameworks 
INTERNATIONAL JOURNAL OF ACADEMIC RESEARCH IN BUSINESS AND SOCIAL SCIENCES

Vol. 10, No. 15, Youth and Community Wellbeing: Issues, Challenges and Opportunities for Empowerment V1. 2020, E-ISSN: 2222-6990 @ 2020 HRMARS

based on psychometric theories to describe the financial behaviour (Masuo et. al., 2004). Further, financial issue related studies revealed that money attitude plays a vital role in influencing household's financial management, and the FWB (Shim et. al., 2009). Further evidence has suggested that money attitudes lead the improvement of the money behaviour (Roberts \& Jones, 2001), as such, money attitudes are important to forecast the financial practices (Dowling et. al., 2009). The development of the financial practices is important to increase the level of FWB, as well as to reduce the individuals' financial vulnerability (Sabri et al., 2020). Therefore, the proposed hypothesis is,

$\mathrm{H}_{\mathrm{a}}$ 7: Money attitude mediates the association between financial behaviour and financial vulnerability

\section{Research Methodology}

Sampling

A cross-sectional survey method was used to examine the financial vulnerability, personal finance (financial literacy and financial behaviour), and psychological factor (money attitude) of the Malaysian households who are working in the public sector. In the first stage of the study, a total of 400 respondents from five (5) zones in Malaysia (i.e. Central, Southern, Northern, Eastern, and East Malaysia) were selected using a multi-stage random sampling method. There are 1.4 million public sector employees under the Public Services Department in Malaysia, and to represent that population, the minimum sample size required is 384 (Israel, 2009). Therefore, 80 respondents were targeted from each zone in each state. At the second stage, government departments which are located in urban areas have been selected from the government websites, and later 20 respondents from each department were selected for the study from the four identified departments randomly.

A series of pre-tests were completed to guarantee the validity, and reliability of the questionnaire. Measurements have been validated for content and construct validities, apartfrom the reliability test. Content validity is assessed through reviews of items from past studies. The departments selected were contacted, and the discussions were held between the researcher and the selected departments regarding data collection. Then, the trained enumerators were sent to the respective departments that agreed to take part in the research, and the responses to the questionnaire were gathered.

Of those participants, $57.5 \%$ of them were female, and $42.5 \%$ were male. The most of the participated workers were Malay ethnic (91.6\%), and followed by Chinese (2.8\%), Indian (2.1\%), and others (2.4\%). The terms of age, this survey consisted of $1 \%$ below 20 years old, 20 to 29 years old (23.5\%), 30 to 39 years old (53.3\%), 40 to 49 years old (15.2\%), and 50 years old and above (7.0\%). When considering the monthly income, less than Ringgit Malaysia (RM)3,000 (42.6\%) was accounted for the largest percentage of the sample followed by RM3,000 - RM4,999 (36.0\%), RM5,000 RM6,999 (17.7\%), RM7,000 - RM8,999 (3.0\%), and more than RM9,000 (0.7\%).

\section{Instrumentation}

A self-administered questionnaire which was based on the items presented in previously published studies was utilized to obtain information on socioeconomic characteristics, personal finance (financial literacy and financial behaviour), psychological factors (money attitude) and financial 
INTERNATIONAL JOURNAL OF ACADEMIC RESEARCH IN BUSINESS AND SOCIAL SCIENCES

Vol. 10, No. 15, Youth and Community Wellbeing: Issues, Challenges and Opportunities for Empowerment V1. 2020, E-ISSN: 2222-6990 @ 2020 HRMARS

vulnerability. Likert- scale measurement was used for the closed-ended items, apart from having open-ended questions (in-depth interview).

\section{Financial Vulnerability}

The dependent variable; financial vulnerability was assessed by means of a ten-point scale with $1=$ very stable/secure finance to $10=$ unstable/unsecured finance which was adopted from Anderloni et al. (2012).

Overall, five items were engaged in financial vulnerability, and they were; "money can be accessed for use when faced with hardships (h8), ability to meet daily needs (h13), ability to meet emergency (h15), have enough money for monthly expenses before receiving the next pay check (h16), and payment/repayment capabilities such as designated (h17)". CFA model values of them were; $d f=5$, Chi-square $/ d f=3.015$, Chi-square $=15.074, \mathrm{RMSEA}=0.059, \mathrm{p}=0.01, \mathrm{GFI}=0.990, \mathrm{NFI}$ $=0.993, \mathrm{CFI}=0.995$, and $\mathrm{TLI}=0.990$.

\section{Financial Behaviour}

The financial behaviour measurements were adopted from the previous instrument by Hilgert et al. (2003), and consisted of four statements based on the five-point Likert scale from 1 (never) to 5 (always). "Use a certified financial planner or adviser to plan for retirement (d13), I periodically check my will (d18), I register with a trustee body for estate business (eg: Malaysia's premier trustee company (ARB) (d20), and I reduce the cost of insurance or takaful (d22)" were the four selected items for the financial behaviour construct, and the values of the CFA model were; $\mathrm{df}=2$, Chi-square $/ \mathrm{df}=$ 3.587, Chi-square $=7.174, \mathrm{RMSEA}=0.067, \mathrm{p}=0.028, \mathrm{GFI}=0.994, \mathrm{NFI}=0.991, \mathrm{CFI}=0.993$, and $\mathrm{TLI}=$ 0.980 .

\section{Financial Literacy}

The financial literacy construct was estimated by an instrument of Sabri et. al. (2010), which was established for the Malaysian context with true or false answers. There were four main statements of financial literacy in the construct; "the longer the repayment period the lower the cost of the overall loan (c1), all types of investments are profitable and low risk (c3), all investments in Malaysia are legal (c4), and Private Retirement Scheme is only for government employees (c6)". The related CFA model values were; $\mathrm{df}=5$, Chi-square $/ \mathrm{df}=1.178$, Chi-square $=5.890, \mathrm{RMSEA}=0.0 .18, \mathrm{p}=0.000, \mathrm{GFI}=$ 0.996, $\mathrm{NFI}=0.970, \mathrm{CFI}=0.995$, and $\mathrm{TLI}=0.990$.

\section{Money Attitude}

Measurement statements of money attitude were adopted from Furnham (1984), which was followed a four point Likert scale from 1 (strongly disagree) to 4 (strongly agree). The statements for money attitude construct were; "I feel that money is the only thing I can really count on (e2), I put money ahead of pleasure (e9), I firmly believe that money can solve all of my problems (e10), and I will often buy something that is not necessary simply to attract people's attention (e11)". The CFA values for the modified model were; $d f=5$, Chi-square $/ d f=3.057$, Chi-square $=6.114$, RMSEA $=0.060, p=0.047$, $\mathrm{GFI}=0.995, \mathrm{NFI}=0.986, \mathrm{CFI}=0.990$, and $\mathrm{TLI}=0.971$. 
INTERNATIONAL JOURNAL OF ACADEMIC RESEARCH IN BUSINESS AND SOCIAL SCIENCES

Vol. 10, No. 15, Youth and Community Wellbeing: Issues, Challenges and Opportunities for Empowerment V1. 2020, E-ISSN: 2222-6990 @) 2020 HRMARS

\section{Measurement Model}

The proposed research model was empirically evaluated using the maximum likelihood estimation method, and two-step structural equation modeling was followed using the AMOS software. The measurement model was assessed in the first step, and the results are given in Figure 2 . The composite reliability (CR), and average variance extracted (AVE) for the constructs are shown in the Table1.

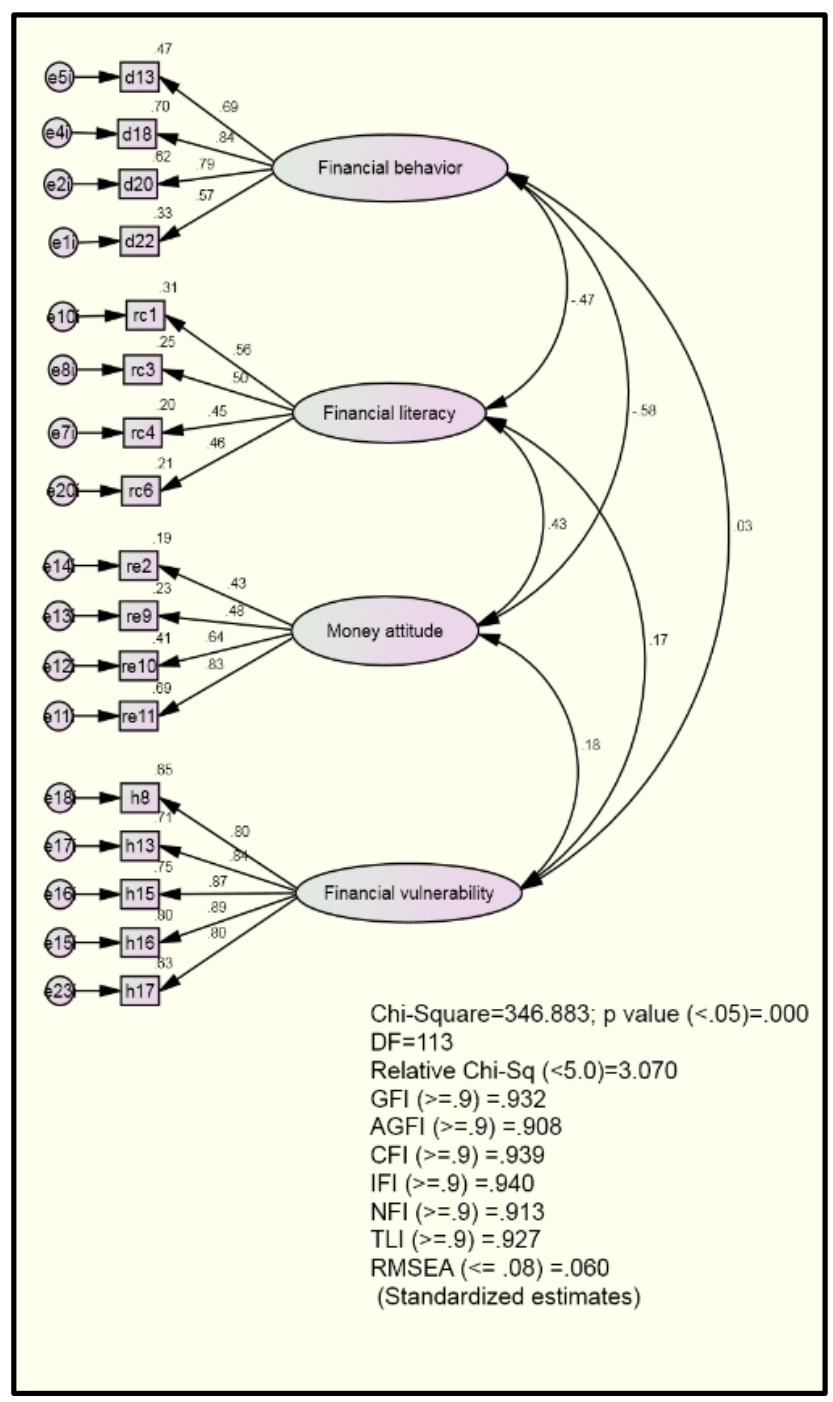

Figure 2: Measurement model 
INTERNATIONAL JOURNAL OF ACADEMIC RESEARCH IN BUSINESS AND SOCIAL SCIENCES

Vol. 10, No. 15, Youth and Community Wellbeing: Issues, Challenges and Opportunities for Empowerment V1. 2020, E-ISSN: 2222-6990 @ 2020 HRMARS

Table 1: The construct validity results

\begin{tabular}{lcc}
\hline \multicolumn{1}{c}{ Construct } & AVE & CR \\
\hline Financial vulnerability & 0.840 & 0.923 \\
Financial behaviour & 0.723 & 0.817 \\
Financial literacy & 0.500 & 0.600 \\
Money attitude & 0.595 & 0.695 \\
\hline
\end{tabular}

According to Hair et. al. (2010), the AVE for the variables was calculated to assess the discriminant validity of the studying variables, and the accepted validity will be achieved, when the AVE value is more than 0.5 (Awang et. al., 2015). All the AVE values given in Table 1 were ranged from 0.500 to 0.840, and the validity of the constructs was accomplished (Hair et al., 2010). Moreover, the composite reliability (CR) should be 0.6 or above to achieve the expected reliability (Awang et al., 2015), and according to the results, it was also fulfilled.

\section{Results and Discussion}

Direct Effects Analysis

A significant association between independent, and dependent variables can be observed, when the $t$ value is $\geq 1.96$, and the $p$ value is $<0.05$ at the $95 \%$ confidence level (Byrne, 2001).

Table 2 Regression results of the modified model

\begin{tabular}{lclcccc}
\hline Estimated Path & & & S.E & $t$ & $p$ \\
\hline Financial vulnerability & $\leftarrow$ Money attitude & 0.990 & 0.296 & 3.342 & $* * *$ \\
Money attitude & $\leftarrow$ Financial literacy & 0.536 & 0.193 & 2.779 & 0.005 \\
Financial vulnerability & $\leftarrow$ Financial literacy & 1.918 & 0.814 & 2.355 & 0.019 \\
Financial vulnerability & $\leftarrow$ Financial behaviour & 0.810 & 0.216 & 3.746 & $* * *$ \\
Money attitude & $\leftarrow$ Financial behaviour & -0.374 & 0.060 & -6.252 & $* * *$ \\
\hline
\end{tabular}

Note: S.E $=$ Standard Error; ${ }^{* * *}$ p significant at $<0.001$

When considering the relationship between money attitude, and financial vulnerability, the $t$ value is 3.342, and $p$ value is 0.001 . It indicates a significant association between the variables, and $\mathrm{H}_{\mathrm{a}} 1$ was accepted. The value of $t=2.355$, and $p=0.019$ for the association between financial literacy, and financial vulnerability was significant. Hence, the $\mathrm{H}_{\mathrm{a}} 2$ was accepted. Furthermore, according to the results of the Table 2, the association between financial behaviour, and financial vulnerabili ty was signifiant in the probability level of 0.001 , and $\mathrm{H}_{\mathrm{a}} 3$ was accepted. The association between financial behaviour, and money attitude was studied via the fourth hypothesis, and the fifth hypothesis examines the association between money attitude and financial literacy. In both cases, $t$ and $p$ values were fulfilled the requirements, and therefore, both $\mathrm{H}_{a} 4$ and $\mathrm{H}_{\mathrm{a}} 5$ were also accepted.

\section{Mediating Effects Analysis}

The mediating test results for the associations between personal finance (financial behaviour, financial literacy), money attitude, and financial vulnerability are given in the Figure 3 . Prior to 
INTERNATIONAL JOURNAL OF ACADEMIC RESEARCH IN BUSINESS AND SOCIAL SCIENCES

Vol. 10, No. 15, Youth and Community Wellbeing: Issues, Challenges and Opportunities for Empowerment V1. 2020, E-ISSN: 2222-6990 @) 2020 HRMARS

conduct a mediator test, a mediator model should be established to examine the direct effect between financial literacy (LV), financial behaviour (BV), and financial vulnerability (BV). While the indirect effect involves the association between financial literacy (LA), and financial behaviour (FA) through a money attitude towards financial vulnerability (AV).

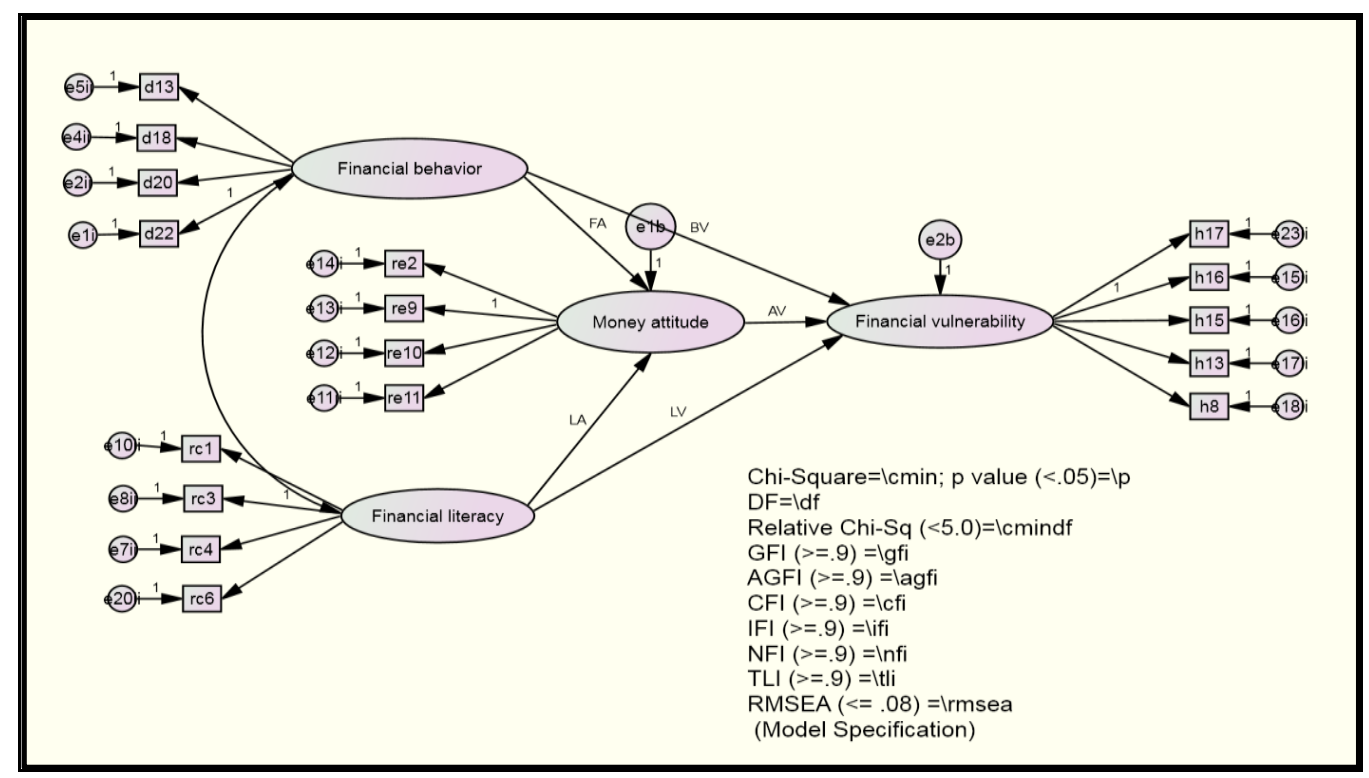

Figure 3 Mediation model

The RMSEA $=0.60, \mathrm{CFI}=0.939, \mathrm{NFI}=0.913, \mathrm{TLI}=0.927$, and $x^{2} / \mathrm{df}=3.070$ are the fit indices of the structural model (full mediation model), and the GOF indices; TLI and CFI were over the cut-off point of 0.90, and hence, results have been significant. Moreover, the RMSEA value is below 0.8, and chisquare/df value of 3.070 have revealed the satisfactory conditions to fit the model. Further, the NFI estimation was above the minimum value of 0.90 , and the NFI and CFI values are from the similar group of incremental fit indices (Byrne, 2010). Therefore, the model fit was proved, and the test of the hypothesis has been conducted with two phases; (1) determination of the direct effect of the independent variables without mediation effect (Figure 4); and (2) determination of the direct structural model with mediation effect (Figure 5). 


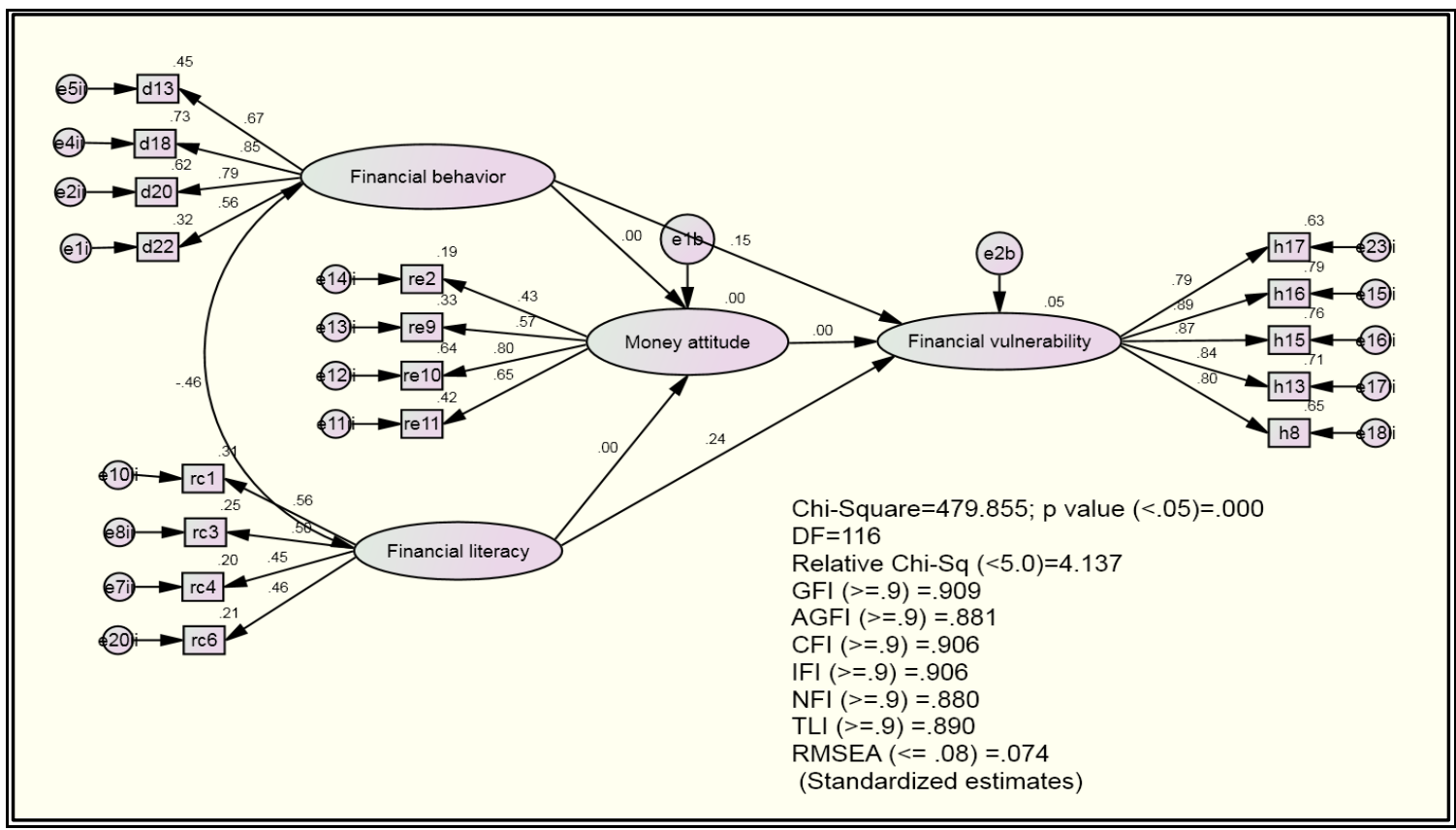

Figure 4 Direct model without mediation

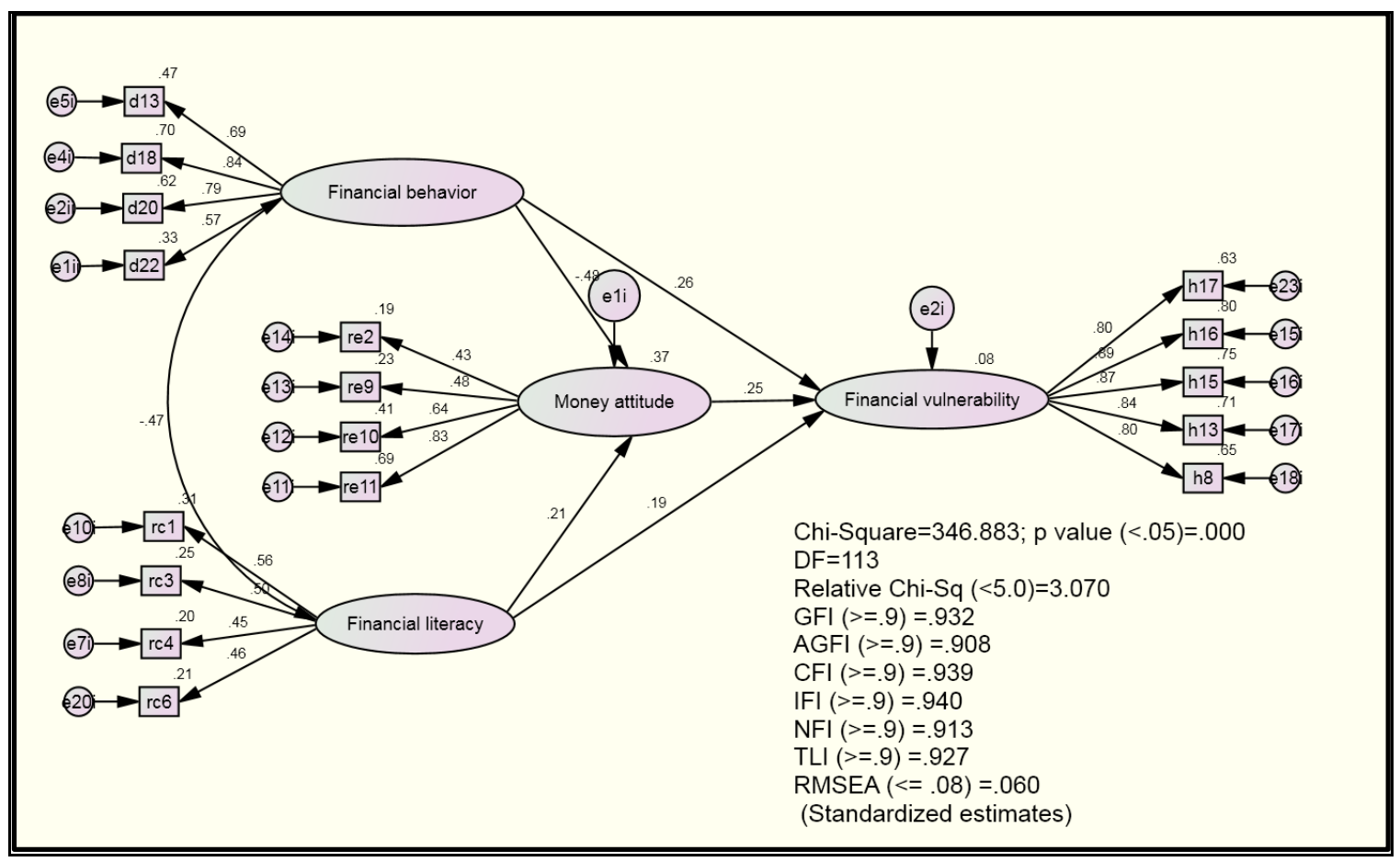

Figure 5 Full mediation model

The mediating test was performed to reveal the effect of money attitude on the link between financial behaviour, and financial literacy with financial vulnerability. A noteworthy direct effect was revealed between financial literacy (beta coefficient $(b c)=0.730, p=0.001$ ), and financial behaviour ( $b c=0.187, p=0.014$ ) with financial vulnerability(Table 3 ). Based on the findings of Baron and Kenny 
INTERNATIONAL JOURNAL OF ACADEMIC RESEARCH IN BUSINESS AND SOCIAL SCIENCES

Vol. 10, No. 15, Youth and Community Wellbeing: Issues, Challenges and Opportunities for Empowerment V1. 2020, E-ISSN: 2222-6990 @ 2020 HRMARS

(1986), significant associations for the direct model, and full mediation model with reduction of the Beta values exhibit a partial mediation. Based on the results obtained, the causal effect of financial literacy $(b c=0.238, p=0.001$ ) on financial vulnerability (beta coefficient $=0.186, p=0.013$ ) was reduced, but still remains significant. The result also revealed the causal effect of financial behaviour ( $b c=0.147, p=0.014)$ on financial vulnerability $(b c=0.263, p=0.001$ ) was failed to decrreaced, but still remains significant. According to Awang (2012), if the effect of moderator variable in the model fails to reduce the value of the mediation model, then there is no moderation effect in the relationship.

According to the findings of Baron and Kenny (1986), money attitude was partially mediated the the association between financial literacy, and financial vulnerability. Further, the partial mediation was tested with significance test, and the results were compatible with the criteria which was given by Baron and Kenny (1986). Therefore, the $\mathrm{H}_{a} 6$ was accepted. However, there is no moderation effect of money attitude on the association between financial behaviour, and financial vulnerability. Therefore, the hypothesis $\mathrm{H}_{\mathrm{a}} 7$ was rejected.

Table 3 The results of mediation effect of money attitude on the relationship between financial literacy, financial Behaviour, and financial vulnerability

\begin{tabular}{lccccc}
\hline \multicolumn{1}{c}{ Path } & $b$ & $S E$ & Beta & $C R$ & $p$ \\
\hline \multicolumn{1}{c}{ Direct Model : } & & & & & \\
a1) Financial literacy $\rightarrow$ Financial vul nerability & 2.329 & 0.730 & 0.238 & 3.192 & 0.001 \\
b1) Financial behaviour $\rightarrow$ Financial vulnerability & 0.459 & 0.187 & 0.147 & 2.451 & 0.014 \\
& & & & & \\
Mediation Model : & & & & & \\
a1) Financial literacy $\rightarrow$ Financial vulnerability & 1.812 & 0.728 & 0.186 & 2.490 & 0.013 \\
a2) Financial literacy $\rightarrow$ money attitude & 0.507 & 0.179 & 0.205 & 2.823 & 0.005 \\
a3) Money attitude $\rightarrow$ Financial vulnerability & 0.990 & 0.282 & 0.250 & 3.511 & 0.001 \\
b1) Financial behaviour $\rightarrow$ Financial vulnerability & 0.810 & 0.216 & 0.263 & 3.757 & 0.001 \\
b2) Financial behaviour $\rightarrow$ money attitude & -.374 & 0.060 & -.482 & -6.26 & 0.001 \\
b3) Money attitude $\rightarrow$ Financial vulnerability & 0.990 & 0.282 & 0.250 & 3.511 & 0.001 \\
\hline
\end{tabular}

Note. *p significant at $<0.05$

\section{Conclusions}

The findings of this research have confirmed that financial behaviour, financial literacy, and money attitude have significant relationships with financial vulnerability among Malaysian households. The financial vulnerability has become increasingly important concern by various parties to overcome the biggest challenges that are facing by the Malaysian individuals, as well as households nowadays, because making financial mistakes in life can be costly with in the demanding financial environment (Lee \& Sabri, 2017). Nonetheless, few past studies have drawn attention to financial vulne rability as a vital concept, and as a significant factor in measuring the households' financial environment. Moreover, household level of financial vulnerability is studied in terms of their credit rationing, risk coping ability, and attitudes towards shock in (Al-Mamun \& Mazumder, 2015; Emmons \& Noeth, 2013). 
INTERNATIONAL JOURNAL OF ACADEMIC RESEARCH IN BUSINESS AND SOCIAL SCIENCES

Vol. 10, No. 15, Youth and Community Wellbeing: Issues, Challenges and Opportunities for Empowerment V1. 2020, E-ISSN: 2222-6990 @ 2020 HRMARS

Several past research was confirmed that both financial behaviour and financial literacy have a noteworthy association with money attitude. It is critical to comprehend the individual process involved in developing the capacity to take right financial decisions (Hung et. al., 2009). Integrating the financial knowledge, financial behaviour, and financial attitude together in one model may promote a comprehensive understanding of the subject matter (Serido et. al., 2013). Nonetheless, there are challenges faced in creating a multidisciplinary measure (Yong et. al., 2018), underline the need for various measures that target minimum financial knowledge, behaviour, and attitude to enhance the financial literacy (Potrich et. al., 2016).

Furthermore, studying the mediating effect of the money attitude between financial literacy, and financial vulnerability was revealed that the money attitude act as a partial mediator. However, examination of the mediating effect of the money attitude between financial behaviour, and financial vulnerability was revealed that the money attitude is not a mediator on the given relationship. In conclusion, money attitude affects only on the association between financial literacy, and financial vulnerability. Hence, money attitude is not affected on the association between financial behaviour, and financial vulnerability among Malaysian households who are working in the public sector. Various examinations in the field of economic psychology were analyzed individuals' beliefs or attitudes about the money. This attention is undoubtedly due to the increasing awareness of the scholars on individual dissimilarities in money attitudes, for instance, in planning motivational schemes for the workplace, just as in studying consumption, saving, and debt behaviour (Hayhoe et. al., 2012). Empirical studies supported the concept of financial knowledge through financial education programmes to enhance the money attitude, which has a major effect on financial behaviour (Batty et. al., 2015), and the effectiveness of the programme would be enhanced further if they pay attention on the participants' gender and the ethnicity (Sabri \& Wijekoon, 2019).

\section{Implications, limitations and Future Research}

Personal finance among household needs to be emphasized in reducing their financial vulnerability. There are different possibilities for an individual being financially vulnerable. Malaysia is more emphasized the social and psychological perspectives by using the variables, for example, social, ability, cognitive, and chronological factors in order to quantify the financial vulnerability of the family units (Lee \& Sabri, 2017). The results of the current study might be usful for policymakers, and numerous relevant agencies to comprehend the financial vulnerability among households via their financial behaviour, financial literacy, and money attitude.

The findings have also confirmed that financial behaviour, financial literacy, and money attitude have a noteworthy association with the financial vulnerability. There are two reasons for monitoring the financial health of indebted households. First, families' incapability to pay their debt on time might have negative impact on their bank savings. Second, elevated levels of family indebtedness are sensitive to the economic shocks (Michelangeli \& Rampazzi, 2016), and the raising up in families' debt that commonly anticipate the financial catastrophes (Brown et al., 2010). The inability of a household to overcome from unexpected financial shocks could be explained as the financial vulnerability (Abid \& Shafiai, 2018). Hence, it is critical to highlight the determinants of the financial vulnerability. In 
INTERNATIONAL JOURNAL OF ACADEMIC RESEARCH IN BUSINESS AND SOCIAL SCIENCES

Vol. 10, No. 15, Youth and Community Wellbeing: Issues, Challenges and Opportunities for Empowerment V1. 2020, E-ISSN: 2222-6990 @ 2020 HRMARS

addition, attention on the elements that cause financial vulnerability of the households to financial shocks is crucial in family economic studies.

The findings also indicated that the money attitude was a partial mediator on the link between financial literacy, and financial vulnerability. But, money attitude did not mediate the relationship between the financial behaviour, and financial vulnerability. This finding may encourage relevant authorities in setting up a financial module, and upgrading of the explicit policies to express the concern about the vulnerability of households to economic shocks, for example, unexpected job loss.

Some limitations are associated with the current study; the concepts and measurements of the variables are restricted to money attitude, financial literacy, financial behaviour, and financial vulnerability. Therefore, the outcomes are also stagnated to the selected variables, but future research should concern the other variables that are important to measure the financial vulnerability. Further, the sample of the current study involved only the Malaysian households working in the public sector, but in future studies more representative samples can be used to represent the whole population of Malaysia.

\section{Acknowledgments}

This study was funded by the Ministry of Higher Education Malaysia under the Fundamental Research Grant Scheme through Universiti Putra Malaysia (FRGS/1/2016/SS03/UPM/02/04 - Development of Financial Vulnerability Model for Malaysian Households Towards Achieving Financial Sustainability).

\section{References}

Abdul Ghani, N. (2010). Household indebtedness and its implication for financial stability in Malaysians. In D. Nokarnthab (Ed.), Household indebtedness and its impact for financial stability (pp. 67-88). The South East Asian Central Banks (SEACEN) Research and Training Centre.

Abid, A., \& Shafiai, M. H. M. (2018). Determinants of household financial vulnerability in Malaysia and its effect on low-income groups. Journal of Emerging Economies \& Islamic Research, 6(1), 32-43.

Ahmad, N. W., Ripain, N., Bahari, N. F., \& Shahar, W. S. S. (2016). The impact of financial literacy on financial behaviour: a literature study. Proceeding of the $2^{\text {nd }}$ International Conference on Economics \& Banking 2016 ( $2^{\text {nd }}$ ICEB), e-ISBN: 978-967-0850-40-5.

Albeerdy, M. I., \& Gharleghi, B. (2015). Determinants of the financial literacy among college students in Malaysia. International Journal of Business Administration, 6(3), 15-24.

Al-Mamun, A., \& Mazumder, M. N. H. (2015). Impact of microcredit on income, poverty, and economic vulnerability in Peninsular Malaysia. Development In Practice, 25(3), 333-346. https://doi:10.5430/ijba.v6n3p15.

Anderloni, L., Bacchiocchi, E., \& Vandone, D. (2012). Household financial vulnerability: An empirical analysis. Research in Economics, 66(3), 284-296. https://doi. org/ 10. 1016/ j.rie.2012.03.001. 
INTERNATIONAL JOURNAL OF ACADEMIC RESEARCH IN BUSINESS AND SOCIAL SCIENCES

Vol. 10, No. 15, Youth and Community Wellbeing: Issues, Challenges and Opportunities for Empowerment V1. 2020, E-ISSN: 2222-6990 @ 2020 HRMARS

Aranda, M. P., \& Lincoln, K. D. (2011). Financial strain, negative interaction, coping styles and mental health among low-income Latinos. Race and Social Problems, 3, 280-297. https://doi. 10.1007/s12552-011-9060-4.

Arashiro, Z. (2011). Money matters in times of change: financial vulnerability through the life course. Brotherhood of St. Laurence, Victoria, Accessed on 20 August 2020 from http://www.bsl.org.au/pdfs/Arashiro_Money_matters_times_of_change_2011.pdf.

Awang, Z. (2012). Structural equation modeling using AMOS graphic. Penerbit Universiti Teknologi MARA.

Awang, Z., Afthanorhan, A., \& Asri, M. A. M. (2015). Parametric and non parametric approach in structural equation modeling (SEM): The application of bootstrapping. Modern Applied Science, 9(9), 58-67. https://doi:10.5539/mas.v9n9p58.

Baron, R. M., \& Kenny, D. A. (1986). The moderator-mediator variable distinction in social psychological research: Conceptual, strategic, and statistical considerations. Journal of Personality and Social Psychology, 51(6), 1173-1182.

Batty, M., Collins, J. M., \& Odders-White, E. (2015). Experimental evidence on the effects of financial education on elementary school students' knowledge, behavior, and attitudes. Journal of Consumer Affairs, 49(1), 69-96. https://doi: 10.1111/joca.12058.

Boon, T. H., Yee, H. S., \& Ting, H. W. (2011). Financial literacy and personal financial planning in Klang Valley, Malaysia. International Journal of Economics and Management, 5(1), 149168.

Brown, M., Haughwout, A. F., Lee, D., \& Van der Klaauw, W. (2010). The financial crisis at the kitchen table: trends in household debt and credit. Federal Reserve Bank of New York Staff Reports, 480.

Byrne, B. M. (2001). Structural equation modeling with AMOS, EQS, and LISREL: Comparative approaches to testing for the factorial validity of a measuring instrument. International Journal of Testing, 1(1), 55-86. https://doi: 10. 1207/ S15327574IJT0101_4.

Byrne, B. M. (2010). Structural equation modeling with AMOS: basic concepts, applications, and programming (multivariate applications series). New York: Taylor \& Francis Group, 396, 7384.

Chambers, R. (1989). Editorial introduction: vulnerability, coping and policy. IDS Bulletin, 20(2), 17.

Choi, L. (2009). Financial stress and its physical effects on individuals and communities. Community development. Investment Review, 5(3), 120-122.

Chou, K. L., \& Chi, I. (2001). Financial strain and depressive symptoms in Hong Kong elderly Chinese: The moderating or mediating effect of sense of control. Aging \& Mental Health, 5(1), 23-30. https://doi:10.1080/13607860020020609.

Culbertson, H. M. (1968). What is an attitude? Journal of Cooperative Extension, 6(2), 79-84.

De Clercq, B., Van Tonder, J. A., \& Van Aardt, C. J. (2015). Consumer financial vulnerability: Identifying transmission linkages that could give rise to higher levels of consumer financial vulnerability. Southern African Business Review, 19(1), 112-136. https://doi: 10.25159/1998-8125/5836.

Deacon, R. E., \& Firebaugh, F. M. (1988). Family resource management: Principles and applications, Allyn \& Bacon. 
INTERNATIONAL JOURNAL OF ACADEMIC RESEARCH IN BUSINESS AND SOCIAL SCIENCES

Vol. 10, No. 15, Youth and Community Wellbeing: Issues, Challenges and Opportunities for Empowerment V1. 2020, E-ISSN: 2222-6990 @ 2020 HRMARS

Dowling, N. A., Corney T., \& Hoiles L. (2009). Financial management practices and money attitudes as determinants of financial problems and dissatisfaction in young male Australian workers. Journal of Financial Counseling and Planning, 20(2), 5-13.

Emmons, W. R., \& Noeth, B. J. (2013). Economic vulnerability and financial fragility. Federal Reserve Bank of St. Louis Review, 95(5), 361-388.

Engelberg, E., \& Sjöberg, L. (2006). Money attitudes and emotional intelligence. Journal of Applied Social Psychology, 36(8), 2027-2047. https://doi:10.1111/j.0021-9029. 2006.00092.x.

Fei, C. K., Sabri, M. F., Mohamed, N. A., Wijekoon, R., \& Majid A. Z. A. (2020). Determinants of financial vulnerability among young employees in Malaysia. Journal of Critical Reviews, 7(15), 3097-3107. https://doi:10.31838/jcr.07.15.425.

Folkman, S., Lazarus, R. S., Gruen, R. J., \& DeLongis, A. (1986). Appraisal, coping, health status, and psychological symptoms. Journal of Personality and Social Psychology, 50 (3), 571-579.

Furnham, A. (1984). Many sides of a coin: The psychology of money usage. Personality and Individual Differences, 5(5), 95-103. https://doi:10.1016/0191-8869(84)90025-4.

Gorgievski, M. J., Bakker, A. B., Schaufeli, W. B., Van der Veen, H. B., \& Giessen, C. W. M. (2010). Financial problems and psychological distress: Investigating reciprocal effects among business owners. Journal of Organizational and Occupational Psychology, 83 (2), 513-530. https://doi:10.1348/096317909X434032.

Granado, F. J. A., Coady, D., \& Gillingham, R. (2012). The unequal benefits of fuel subsidies: A review of evidence for developing countries, World development, 40(11), 2234-2248. https://doi:10.1016/j.worlddev.2012.05.005.

Hair, J. J. F., Black, W. C., Babin, B. J., Anderson, R. E., \& Tatham, R. L. (2010). SEM: An introduction. Multivariate data analysis: A global perspective, 629-686.

Hayes, D., \& Finney, A. (2013). Genworth Index: Measuring Consumer Financial Security and Vulnerability. The European Credit Research Institute (ECRI).

Hayhoe, C. R., Cho, S. H., DeVaney, S. A., Worthy, S. L., Kim, J., \& Gorham, E. (2012). How do distrust and anxiety affect saving behaviour?. Family and Consumer Sciences Research Journal, 41(1), 69-85. https://doi:10.1111/j.1552-3934.2012.02129.x.

Hilgert, M. A., Hogarth, J. M., \& Beverly, S. G. (2003). Household financial management: The connection between knowledge and behaviour. Federal Reserve Bulletin, 89, 309.

Hung, A., Parker, A. M., \& Yoong, J. (2009). Defining and measuring financial literacy. RAND Working paper WR-708.

Idris, F. H., Krishnan, K. S. D., \& Azmi, N. (2017). Relationship between financial literacy and financial distress among youths in Malaysia-an empirical study. Geografia-Malaysian Journal of Society and Space, 9(4), 106-117.

Israel, G. D. (2009). Determining sample size: program evaluation and organizational development, IFAS. PEOD-6: Florida FL: University of Florida.

Kapoor, J. R., Dlabay, L. D., \& Hughes, R. J. (2004). Personal finance. McGraw-Hill, New York, NY.

Lee, M. P., \& Sabri, M. F. (2017). Review of financial vulnerability studies. Archives of Business Research, 5(2), 127-134. https://doi:10.14738/abr.52.2784.

Lusardi, A., \& Mitchell, O. S. (2007). Financial literacy and retirement planning: New evidence from the Rand American Life Panel. Michigan Retirement Research Center Research Paper, 157. 
INTERNATIONAL JOURNAL OF ACADEMIC RESEARCH IN BUSINESS AND SOCIAL SCIENCES

Vol. 10, No. 15, Youth and Community Wellbeing: Issues, Challenges and Opportunities for Empowerment V1. 2020, E-ISSN: 2222-6990 @ 2020 HRMARS

Lusardi, A., \& Mitchell, O. S. (2011). Financial literacy and planning: Implications for retirement wellbeing. National Bureau of Economic Research, 17-39. https://doi: 10.3386/w17078.

Lusardi, A., \& Mitchell, O. S. (2014). The economic importance of financial literacy: Theory and evidence. Journal of Economic Literature, 52(1), 5-44. https:// doi:10. 1257/jel. 52.1.5.

Lusardi, A., \& Tufano, P. (2015). Debt literacy, financial experiences, and over indebtedness. Journal of Pension Economics \& Finance, 14(4), 332-368.

Masuo, D. M., Malroutu, Y. L., Hanashiro, R., \& Kim, J. H. (2004). College student's money beliefs and behaviours: An Asian perspective. Journal of Family and Economic Issues, 25, 469-481. https://doi: 10.1007/s10834-004-5491-z.

Michelangeli, V., \& Rampazzi, C. (2016). Indicators of financial vulnerability: a household level study. Questioni di Economia e Finanza, Bank of Italy, Economic Research and International Relations Area, 369.

Miron-shatz, T. (2009). Am I going to be happy and financially stable? How American women feel when they think about financial security. Judgement and Decision Making, 4(1), 102-112. https://doi:10.2139/ssrn.1329806.

Mokhtar, N., Husniyah, A. R., Sabri, M. F., \& Talib, M. A. (2015). Financial well-being among public employees in Malaysia: A preliminary study. Asian Social Science, 11(18), 49-54. https://doi:10.5539/ass.v11n18p49.

Montano, D. E., \& Kasprzyk, D. (2015). Theory of reasoned action, Theory of Planned Behaviour, and the integrated behavioural model. Health Behaviour: Theory, Research and Practice, 95-124.

Murphy, J. L. (2013). Psychosocial factors and financial literacy. Social Security Bulletin, 73, 73.

Nickerson, C., Schwarz, N., \& Diener, E. (2007). Financial aspirations, financial success, and overall life satisfaction: who? And how? Journal of Happiness Studies, 8(4), 467-515. https://doi:10.1007/s10902-006-9026-1.

OECD. (2013). Women and Financial Education: Evidence, Policy Responses and Guidance. OECD Publishing.

Potrich, A. C. G., Vieira, K. M., \& Mendes-Da-Silva, W. (2016). Development of a financial literacy model for university students. Management Research Review,39(3), 356-376. https://doi:10.1108/MRR-06-2014-0143.

Qamar, M. A. J., Khemta, M. A. N., \& Jamil, H. (2016). How knowledge and financial self-efficacy moderate the relationship between money attitudes and personal financial management behaviour. European Online Journal of Natural and Social Sciences, 5 (2), 296-308.

Roberts, J. A., \& Jones, E. (2001). Money attitudes, credit card use, and compulsive buying among American college students. Journal of Consumer Affairs, 35(2), 213-240. https://doi:10.1111/j.1745-6606.2001.tb00111.x.

Sabri, M. F., \& Wijekoon, R. (2019). The influence of gender and ethnicity on young adults' participation in financial education programme. Journal of Management and Sustainability, 9(1), 159-170. https://doi:10. 5539/ jms. v9n1p159.

Sabri, M. F., \& Zakaria, N. F. (2015). The influence of financial literacy, money attitude, financial strain and financial capability on young employees' fina ncial well-being Pertanika Journal of Social Sciences \& Humanities, 23(4), 827-848. 
Sabri, M. F., MacDonald, M., Hira, T. K., \& Masud, J. (2010). Childhood consumer experience and the financial literacy of college students in Malaysia. Family and Consumer Sciences Research Journal, 38(4), 455-467. https://doi:10.1111/j.1552-3934.2010. 00038.x.

Sabri, M. F., Wijekoon, R., \& Rahim, H. A. (2020). The influence of money attitude, financial practices, self-efficacy and emotion coping on employees' financial wellbeing. Management Science Letters,10(2020), 889-900. https://doi:10.5267/j.msl. 2019.10.007.

Sabri, M. F., Reza, T. S., \& Wijekoon, R. (2020). Financial management, savings and investment behavior and financial well-being of working women in the public sector. Majalah IImiah Bijak, 17(2), 135-153.

Serido, J., Shim, S., \& Tang, C. (2013). A framework for promoting financial capability among young adults', International Journal of Behavioural Development, 37(4), 287-297.

Shih, T. Y., \& Ke, S. C. (2014). Determinates of financial behaviour: insights into consumer money attitudes and financial literacy. Service Business, 8(2), 217-238. https://doi: 10.1007\%2Fs11628-013-0194-x.

Shim, S., Xiao, J. J., Barber, B. L., \& Lyons, A. (2009). Pathways to life success: A conceptual model of financial well-being for young adults. Journal of Applied Developmental Psychology, 30(6), 708-723. https://doi:10.1016/j.appdev.2009.02.003.

Vandone, D. (2009). The determinants of consumer credit: a review of the literature in consumer credit in Europe. Physica-Verlag HD, 7-22.

Yong, C. C., Yew, S. Y., \& Wee, C. K. (2018). Financial knowledge, attitude and behaviour of young working adults in Malaysia. Institutions and Economies, 10(4), 21-48.

Zaimah, R., Sarmila, M. S., Lyndon, N., Azima, A. M., Selvadurai, S., Saad, S., \& Er, A. C. (2013). Financial behaviours of female teachers in Malaysia. Asian Social Science, 9(8), 34.

Zainal, N. R., Kaur, G., Ahmad, N. A., \& Khalili, J. M. (2012). Housing conditions and quality of life of the urban poor in Malaysia. Procedia-Social and BehaviouralSciences, 50(7), 827838. https://doi:10.1016/j.sbspro.2012.08.085.

Zakaria, R. H., Jaafar, N. I. M., \& Marican, S. (2012). Financial behaviour and financial position: a structural equation modelling approach. Middle East Journal of Scientific Research, 12(10), 1396-1402. 